\title{
The geology of the Nanuq kimberlites: new textural varieties in the Western Churchill Province, Canada
}

\author{
K. Webb ${ }^{1}$, M. Harder ${ }^{1}$, P. Holmes ${ }^{2}$, M. Baumgartner ${ }^{1}$, J. Pell ${ }^{2}$ \\ ${ }^{1}$ Mineral Services Canada Inc., Canada; ${ }^{2}$ Peregrine Diamonds Ltd., Canada
}

\section{Introduction}

Three kimberlites, Naturalik, Kayuu and Tudlik, were recently discovered on Peregrine Diamonds Ltd's Nanuq property in Nunavut, northern Canada (Fig. 1). These steep-sided, pipe-shaped bodies were emplaced into Archean granites and gneisses of the Western Churchill structural province. The regional and local geological setting, and the exploration and discovery history are described by Pell et al. (this volume). The pipes are variably filled by coherent (magmatic), apparent coherent and volcaniclastic kimberlite. Kayuu represents the first known occurrence in the eastern Canadian arctic of a pipe filled primarily with mud-rich resedimented volcaniclastic kimberlite (RVK). This rock type is texturally similar to the RVK that characterizes kimberlite bodies of the Lac de Gras province in the central Slave craton.

Logging and petrographic analysis of multiple drill cores, combined with the results of indicator mineral abundance and composition studies form the basis of this contribution. These data are used to define the morphology and internal geology of the two largest pipes, and in conjunction with palynological and radiometric age dating provide insight on the processes and environment of emplacement.

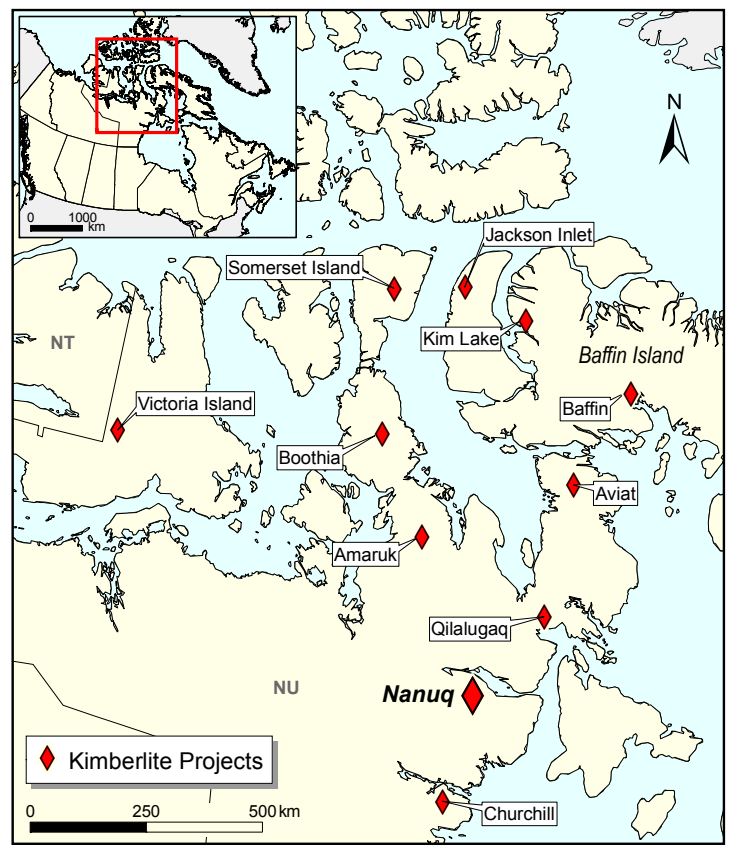

Figure 1: Location of the Nanuq cluster and other kimberlites in the eastern Canadian Arctic.

\section{Naturalik}

Naturalik is the largest of the three kimberlite bodies with a surface area (estimated from geophysics) of roughly 5.8 ha. Intersections in one vertical and five inclined drill cores have been used to construct a threedimensional model of the pipe morphology (Fig. 2). The currently defined model suggests the existence of a single (though poorly constrained) conduit and steepsided crater that is shallower in the south.

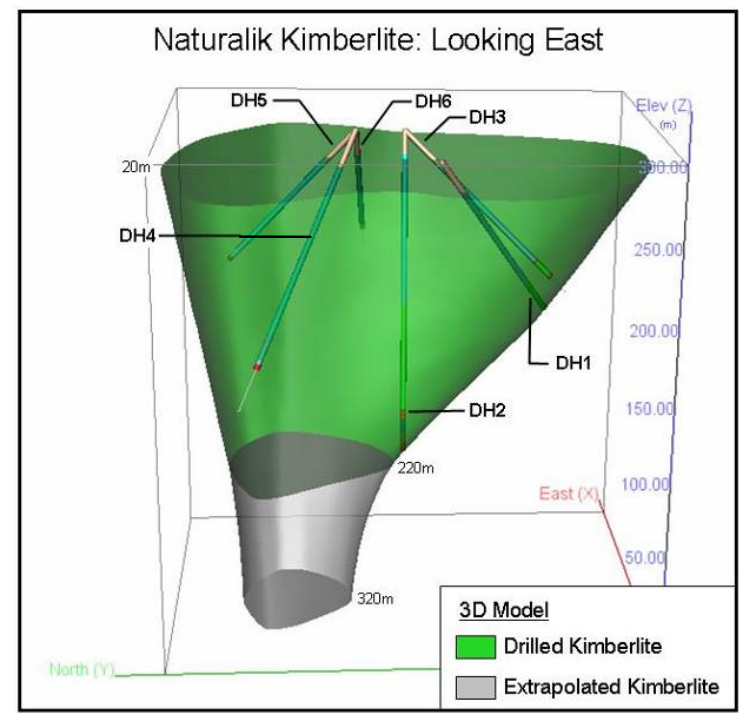

Figure 2: Current three-dimensional geological model of Naturalik showing the pipe morphology and internal geology defined by six drill cores (blue = KIMB-1A and KIMB-1B domains; green = KIMB-2 domain).

The pipe is filled by two contrasting textural varieties: coherent kimberlite (CK) and subordinate variably fragmental volcaniclastic kimberlite (VK). The CK occurs as two generally massive domains: KIMB-1A appears to occur mainly in the south and at the pipe margins in the north, while KIMB-1B occupies the majority of the pipe volume. These competent, fresh rocks (Fig. 3a) are medium-grained and moderately olivine macrocryst rich. The domains are distinguished macroscopically on the basis of contrasting crustal xenolith contents, degree of preservation of mantlederived garnet and abundance of $\mathrm{CK}$ autoliths (cognate lithics), all of which are higher in KIMB-1A. Olivine macrocrysts and phenocrysts display a uniform to locally heterogeneous distribution in a crystalline groundmass (Fig. 3b). Although not common, broken olivine crystals are notably present throughout. 
Mineralogically, both domains are classified as phlogopite monticellite kimberlite, but differ in terms of the abundance and habit of groundmass phlogopite. The magnetic susceptibility of KIMB-1B is double that of KIMB-1A. The VK domain referred to as KIMB-2 underlies the $\mathrm{CK}$ in the south of the body and is texturally and mineralogically distinct. It displays gradational fluctuations in the degree of fragmentation, manifested in variations in the abundance of juvenile clasts, broken olivine grains and matrix ash within VK horizons (Fig. 3c). Localized intercalated intervals of $\mathrm{CK}$ are also present. KIMB-2 is finer-grained and the olivine macrocryst content is lower than the KIMB-1 domains. It is further characterised by a significantly higher abundance of a distinct crustal xenolith suite.

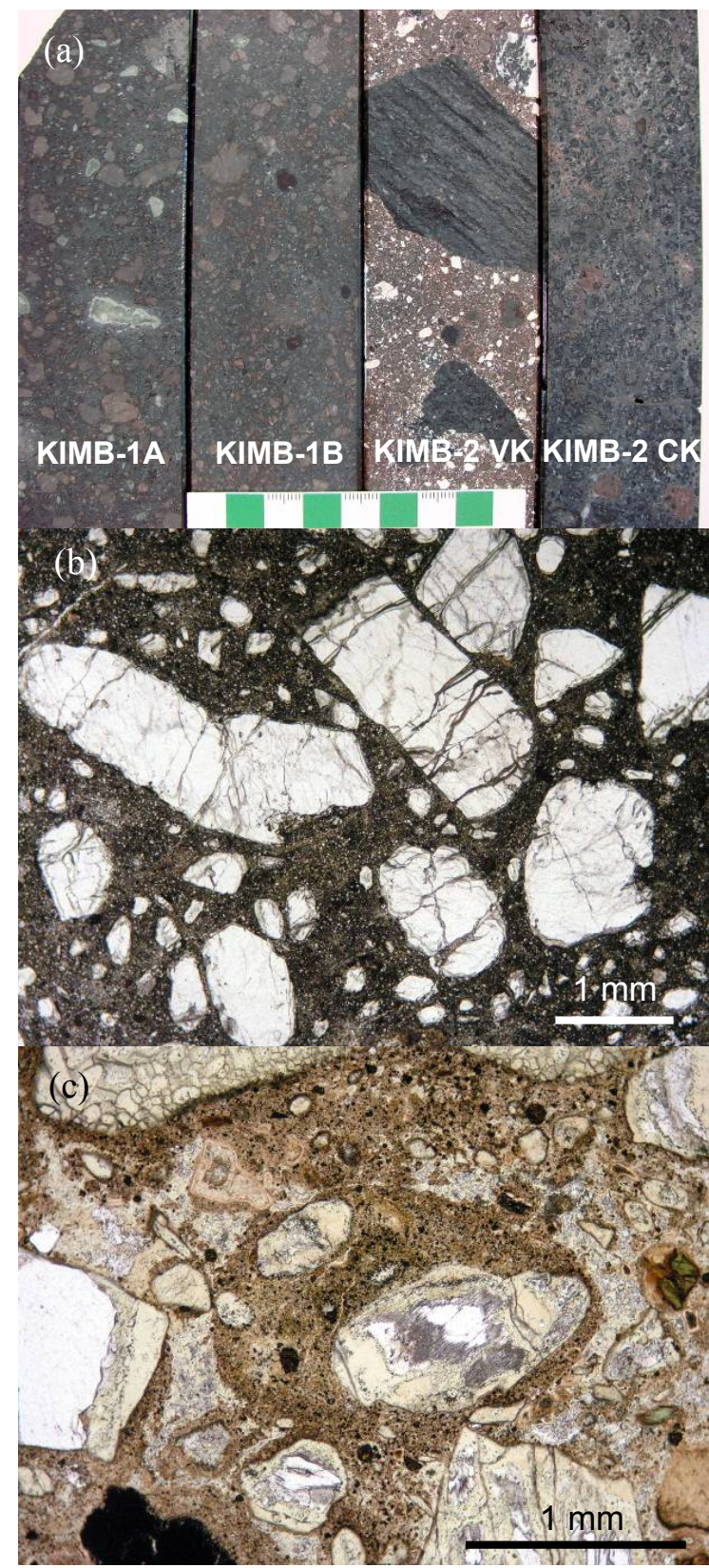

Figure 3: (a) Polished drill core slabs of Naturalik CK and VK domains; photomicrographs of (b) KIMB-1B and(c) KIMB-2 (VK interval).

\section{Kayuu}

The Kayuu kimberlite, located approximately $5 \mathrm{~km}$ west of Naturalik, is estimated from geophysics to be approximately 5 ha at surface and is texturally and structurally complex. The bulk of the pipe fill currently defined in five drill cores (Fig. 4) comprises VK arranged in numerous massive to crudely bedded depositional packages that occur as six spatially and lithologically distinct domains (Table 1; Fig. 5a).

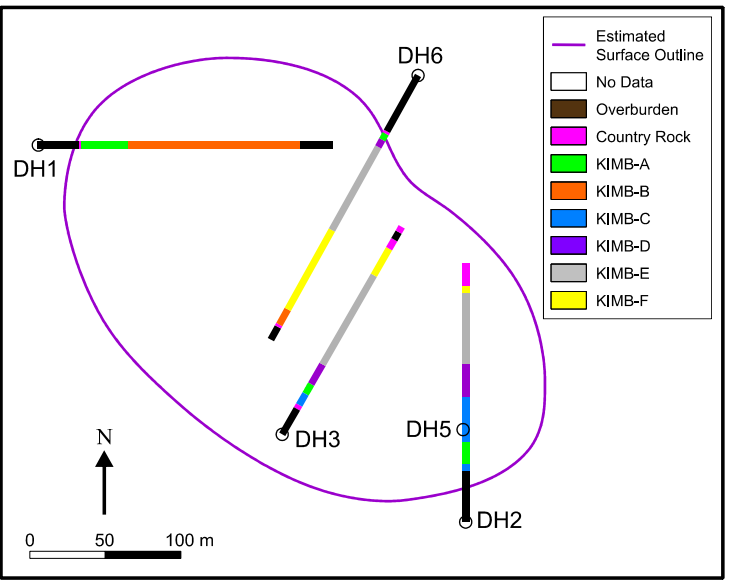

Figure 4: Surface outline of Kayuu showing drill traces projected to surface and currently defined internal geology (refer to Table 1).

KIMB-E is the volumetrically dominant rock type in Kayuu. It is notably characterised by the presence of variable quantities of exotic mud (as soft sediment deformed clasts and disaggregated matrix component; Fig. 5b) and organic fragments (Fig. 5c), as well as a variable olivine content and high abundance of very finely fragmented crustal xenoliths. This complex probable RVK domain is underlain by largely massive possible pyroclastic kimberlite that is considerably diluted by granitic xenoliths up to a few meters in size. KIMB-B appears to be restricted to the north part of the pipe.

Table 1: The six main Kayuu pipe fill domains.

\begin{tabular}{|c|c|}
$\begin{array}{c}\text { Pipe } \\
\text { Domain }\end{array}$ & $\begin{array}{c}\text { Character and } \\
\text { Textural Classification }\end{array}$ \\
\hline KIMB-A & mud-poor VK \\
\hline KIMB-B & variably fragmental VK \\
\hline KIMB-C & kimberlitic sediments \\
\hline KIMB-D & massive 'speckled' VK \\
\hline KIMB-E & alternating variably mud-bearing RVK \\
\hline KIMB-F & granite xenolith-rich VK / PK \\
\hline
\end{tabular}

\section{Tudlik}

Tudlik is a small ( $<1 \mathrm{ha})$ pipe located $200 \mathrm{~m}$ southwest of Kayuu and based on limited drilling to date is filled with generally massive volcaniclastic kimberlite that contrasts in terms of both texture and components to the VK domains in Naturalik and Kayuu. 


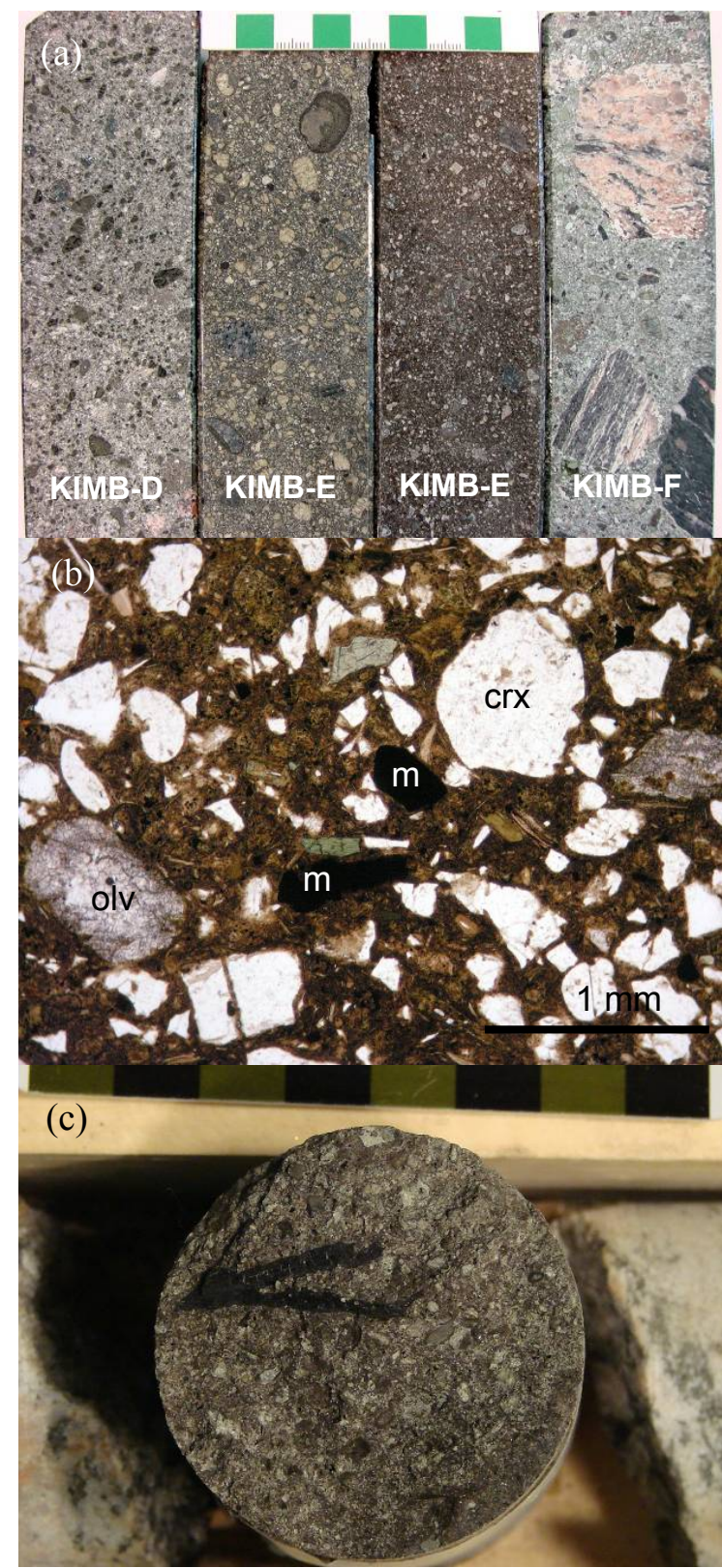

Figure 5: (a) Polished drill core slabs from three of the six Kayuu domains; (b) photomicrograph of KIMB-E showing mud clasts (m), mud-rich matrix, fine crustal xenolith fragments (crx) and minor altered olivine (olv); (c) organic fragment in KIMB-E drill core.

\section{Indicator Mineral Chemistry}

The compositional ranges shown by the indicator minerals from both textural varieties in Naturalik are similar. The garnet assemblages are dominated by high-Cr peridotitic varieties, with lesser but appreciable amounts of low-Cr eclogitic/websteritic components. The Kayuu indicator mineral population is similar to Naturalik, however the overall abundances are lower and the low-Cr garnet assemblage includes a greater proportion of megacrystic varieties. The relative mineral abundances (in particular garnets) of KIMB-B and KIMB-F are distinct from each other and the other domains, supporting the lithological subdivisions.

\section{Palynology and radiometric age dating}

Middle Albian to early Cenomanian palynomorphs and organic debris from two samples of KIMB-E in Kayuu (similar assemblages recovered from mud clasts and mud-rich matrix) place constraints on the time of eruption and suggest a non-marine depositional environment for the included sedimentary material (Sweet, 2007). Preliminary U-Pb isotopic analyses performed on perovskite separated from one sample of KIMB-1B in Naturalik and one of KIMB-A in Kayuu yielded ages of $79.6 \pm 5.2 \mathrm{Ma}$ and $70.4 \pm 5.4 \mathrm{Ma}$, respectively (Heaman, pers. comm.). These data are consistent with the palynology results and reveal that the Nanuq kimberlites are the youngest and first late Cretaceous kimberlites documented in the Churchill province (Heaman et al., 2003; Pell et al., this volume).

\section{Discussion}

The textures, components and internal stratigraphy of the Naturalik pipe fill suggest multiple and varied emplacement events, with the CK likely being extrusive (Webb et al., this volume) and post-dating formation of the variably fragmental VK by eruptions ranging significantly in explosive intensity. The varied character and internal architecture of the Kayuu pipe fill suggests a different, though similarly complex emplacement history to that of Naturalik, involving a spectrum of eruption, deposition and resedimentation processes. The presence of exotic mud and organic fragments in the Kayuu pipe is particularly noteworthy since it suggests the existence of poorly consolidated Cretaceous sediments at surface at the time of eruption. These were subsequently removed by erosion.

\section{Conclusions}

The discovery of the Nanuq kimberlites and the results of this study which highlight the unique geology of these bodies serve to extend the range of kimberlite textures, emplacement styles and intrusion ages present in the Western Churchill province. Kayuu represents the first known occurrence of kimberlite containing surface sedimentary material, the inferred age and depositional environment of which provides insight on the timing and extent of the mid-continental seaway in the eastern Canadian arctic.

\section{References}

Heaman, L.M., Kjarsgaard, B.A. and Creaser, R.A., 2003. The timing of kimberlite magmatism in North America: implications for global kimberlite genesis and diamond exploration; Lithos 71, pp. 153-184.

Pell, J., Holmes, P.K., Grenon, H., Sell, M.V. and Tam, L., this volume. Exploration and discovery of a new kimberlite cluster on the Nanuq property, Western Churchill Province, Kivalliq area, Nunavut. 9IKC Extended Abstracts.

Sweet, A.R., 2007. Applied research on two core samples from kimberlite. Geol. Survey of Canada (Calgary) report 13-ARS-2007; samples P5058-5059.

Webb, K., Crawford, B. Nowicki, T. Hetman, C. and Carlson, J., this volume. Coherent kimberlite at EKATI, Northwest Territories, Canada: textural and geochemical variations and implications for emplacement. 9IKC Extended Abstracts. 